\title{
様々なフロック構造を持つ有機泥の沈降特性
}

\section{Settling Characteristics of Mud Carrying Different Floc Structures}

\author{
小枝豪志 ${ }^{1} \cdot$ 岡村宏信 $^{2} \cdot \mathrm{TOUCH}^{\mathrm{N} A R O N G}{ }^{3} \cdot$ 日比野忠史 ${ }^{4}$ \\ Takeshi KOEDA, Hironobu OKAMURA, Narong TOUCH and Tadashi HIBINO
}

\begin{abstract}
In this study, the settling velocity and organic properties of sedimentation-selected mud flocs were experimentally measured to understand the organic properties, settling characteristics, and flocculation mechanisms in the course of settling. It was found that the settling velocity of mud flocs significantly depended on the amount and properties of adsorbed organic matter. Further, the settling velocity of mud flocs is averaged due to the fact that differences of the settling velocities of particles are diminished under the collision and flocculation of particles in the settling process. Finally, the experiment results suggest that the flocculation of particles adsorbed by large amounts of organic matter was electrically difficult to generate; whereas it was facilitated owing to an increasing positive charge surface of particles by elimination of the organic matter.
\end{abstract}

\section{1. はじめに}

沿岸域における有機泥の沈降特性は, 沿岸環境保護, 生態学，航路計画，水質や物質循環モデルにとって極め て重要な項目である。しかし，有機泥は有機物が微細土 粒子に付着するため, 形状, 粒径, 表面粗さ, 密度に起 因するフロック構造や流体粘性に依存して複雑に挙動す る (Dietrich, 1982). 小枝ら（2010）は，付着有機物量の 異なる有機泥を用いた沈降実験により, 沈降速度が有機 物量と性状に依存していることを示した。一方，平澤ら （2006）は沈降中に粒子のふるい分け・凝集が生じるこ と, 金ら (2009), 阿部ら（2010）は巻き上がり有機泥 の有機性状を分析し, 巻き上がり量は有機泥の有機性状 に依存することを示している．海域に存在する浮遊物質 は無機物と有機物が凝集した不定形の凝集体（フロック） を形成しており，これらのフロックの形成過程は乱流， 沈降速度差, ブラウン運動による複数の粒子の接触によ って生じることが知られている (Eisma et al., 1991).さ らに海域での沈降泥の凝集は有機物量によって異なり, 有機物は凝集過程において微細土粒子の接着材としての 役割を果たすことが報告されている（Wilkinson et al., 1997)。粒子の運動に強い影響を及ぼす浮遊時の凝集に ついての知見は多いにも関わらず，有機泥の構造の変化 と運動の関係について調べた例は少ない.

本研究では有機泥を沈降速度別に選別し, 沈降泥の有 機性状（フロック構造）と沈降速度との関係を明らかに

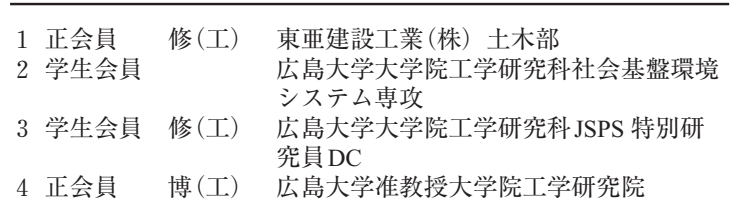

した.さらに, 有機物が混在することによる有機物量の 異なる有機泥粒子群の凝集について考察した.

\section{2. 有機泥の沈降特性を把握するための実験}

\section{（1）実験に用いた試料}

本研究に用いた有機泥は 2010 年夏期に広島湾奥部に位 置する海田湾において海底から $10 \mathrm{~cm}$ の高さに開口部を 出して埋設したセデイメントトラップに捕捉された有機 泥である．実験では，捕捉泥を沈降速度（時間）により 選別した試料を用いた. 有機物の付着状態が沈降に及ほ す効果を検討するため, 過酸化水素水により有機物を除 去し, 有機泥のフロック構造を壊した試料も準備した。 選別された有機泥群特性は表-1に示されている.

（2）沈降時間による有機泥群の選別

海田湾海底で捕捉された有機泥（Case 1）を室温 $\left(27^{\circ} \mathrm{C}\right)$ に保って沈降速度別に選別した。選別作業には 縦 $39 \mathrm{~cm}$, 横 $56 \mathrm{~cm}$, 高さ $31 \mathrm{~cm}$ の容積約 $6800 \mathrm{~cm}^{3}$ の容器が 用いられた。捕捉有機泥は表-1に示す時間に区切って選 別された。例えば 6.6 時間以上沈降しない懸濁粒子 (Case 7) の採取方法は以下のとおりである. 容器内に $30 \mathrm{psu}$ の塩水と有機泥を投入し擋挥する. 6.6 時間静置し た後，水面から約 $5 \mathrm{~cm}$ までの濁水をサイフォンにより採 水する. 採水により減量した分の塩水を追加する. 以降, 撹拌, 沈降, 採水, 塩水追加の作業を繰り返す. 約 $5 \mathrm{~cm}$ 以浅の濁水濃度が 20 度（OPTEX, TD-M500）以下にな った時点で6.6時間以上沈降しない懸濁物質 (Case 7) の ふるい分けを終了とした。ここでは濁水濃度が 20 度以下 になった時点で 6.6 時間以上沈降しない懸濁粒子がすべ て採取されたものとしている.つまり次のステップであ る 1 時間から 6.6 時間 (Case 6) に沈降する矁濁物質は 1 時間静置後に採水した試料となる。選別はCase 7 から 
表-1 試料概要

\begin{tabular}{|c|c|c|c|c|c|c|}
\hline Case No. & $\left|\begin{array}{c}\text { Sampling } \\
\text { conditions }\end{array}\right| A$ & $\begin{array}{c}\text { Addition of } \\
\mathrm{H}_{2} \mathrm{O}_{2}\end{array}$ & $\begin{array}{l}\mathrm{D}_{50} \\
{[\mathrm{~m}]}\end{array}$ & $\begin{array}{l}\text { IL } \\
{[\%]}\end{array}$ & $\begin{array}{c}\mathrm{C} \\
{[\mathrm{mg} / \mathrm{g}]}\end{array}$ & $\begin{array}{c}\mathrm{C} / \mathrm{N} \text { ratio } \\
{[-]}\end{array}$ \\
\hline Case 1 & raw & \multirow{7}{*}{ No } & 24.6 & 16.6 & 50.2 & 12.5 \\
\hline Case 2 & $0-5 \mathrm{~min}$ & & 34.8 & 12.3 & 52.0 & 14.9 \\
\hline Case 3 & 5-20min & & 29.0 & 15.6 & 48.1 & 12.1 \\
\hline Case 4 & $20-40 \mathrm{~min}$ & & 25.8 & 18.1 & 48.8 & 11.3 \\
\hline Case 5 & $40-60 \mathrm{~min}$ & & 22.1 & 15.4 & 47.0 & 11.9 \\
\hline Case 6 & $1-6.6 \mathrm{~h}$ & & 9.7 & 17.0 & 38.6 & 10.1 \\
\hline Case 7 & over6.6h & & 6.1 & 21.6 & 61.9 & 8.1 \\
\hline Case $1 \mathrm{~b}$ & raw & Yes & 16.1 & 10.7 & - & - \\
\hline
\end{tabular}

※D50: 中央粒径, IL: 燃焼物重量, C: 炭素含有量

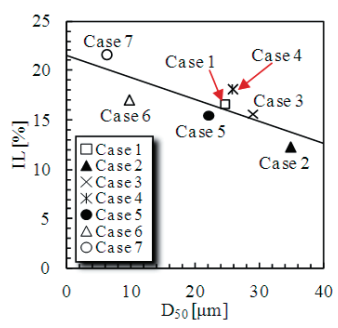

(a) $\mathrm{D}_{50} \sim \mathrm{IL}$ の関係

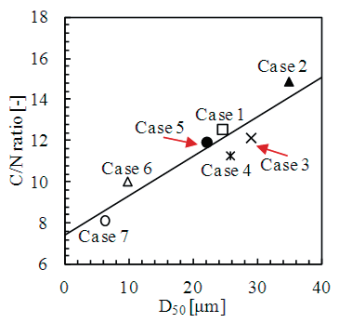

(b) $\mathrm{D}_{50} \sim \mathrm{C} / \mathrm{N}$ 比の関係
図-1 沈降選別された沈降泥の有機特性

Case 2の順に行なわれた。なお，Case 7 の採取時間（6.6 h）は内田ら（1987）の研究を基に決定した.

\section{（3）測定項目および測定方法}

測定項目は $\mathrm{C} / \mathrm{N}$ 比 (有機性状), IL (燃焼物重量), 粒 度分布，沈降速度である。選別された有機泥は顕微鏡写 真により形状を確認した。ILは塩分による影響を除くた め，有機泥の遠心分離 $(10000 \mathrm{G} ， 5$ 分）行った後に測定 した。 C/N 比はCHNS 分析装置（パーキンエルマー製 CHNS/0 2400II）で測定された炭素と窒素含有量により推 定した。沈降速度はレーザ回折式粒度分布計（島津製作 所社製：SALD-2000J）で測定された粒度分布の変化に より推定した．粒度分布からの沈降速度の推定は西村ら （2009）による方法を用いた。本手法による沈降速度推 定精度については，10\%以下の再現誤差であることが小 枝ら（2011）により報告されている。

\section{3. 沈降速度別に選別された有機泥群の沈降特性}

\section{（1）有機泥群の粒子特性}

図-1には沈降速度別に選別された沈降泥の中央粒径 $\left(\mathrm{D}_{50}\right)$ に対する（a）燃焼物重量％(IL)，（b） C/N比との 関係，図-2には代表される粒子群の粒度分布が示されて いる. 写真-1には沈降選別された沈降泥の顕微鏡写真が 示されている。沈降時間によって選別された有機泥群は 粒径によってのみ分類されておらず，付着有機物にも依 存していることがわかる．また，表-1に示した中央粒径

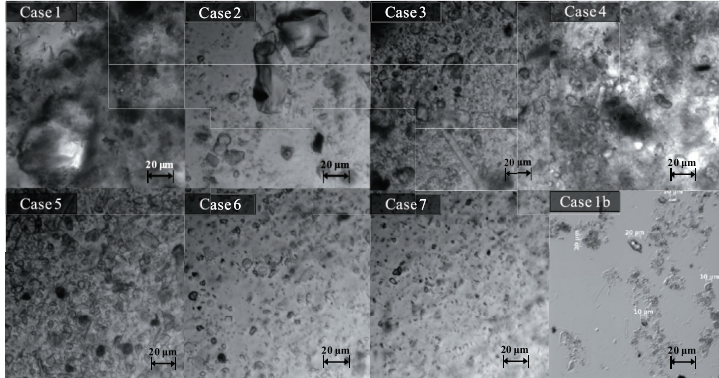

写真-1 沈降選別された有機泥群の顕微鏡写真

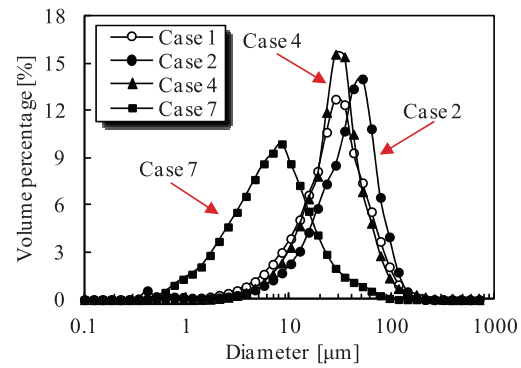

図-2 沈降選別された沈降泥の粒度分布

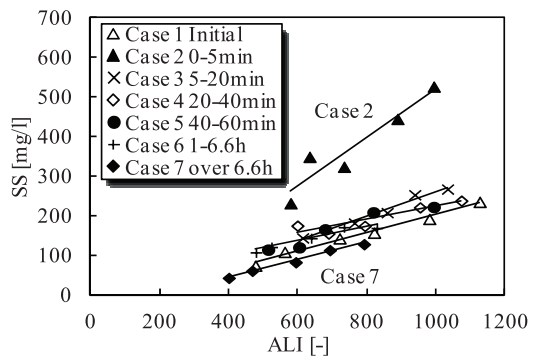

図-3 沈降選別された沈降泥の SS と平均光強度 (ALI)の関係

から 6つの有機泥群は Case 2〜 5 と Case 6，7の2つのグル ープに大別することができる．2つのグループでは $\mathrm{C} / \mathrm{N}$ 比 に差があり，付着する有機泥の性状によって付着できる 粒子径が変化することが考えられ, Case 6 と7ではC/N比 の低い比較的新鮮な有機物が微細粒子に付着できている.

有機物を除去してフロック構造を破壊した有機泥群 （Case 1b）の顕微鏡写真では，白色半透明に映る鉱物が 多く，粒子は個々に存在している。これに対し, Case 1 〜 5 顕微鏡写真では黒色の部分と白色半透明な部分が 混在しており，有機物と鉱物とが複雑に絡み合ってフロ ックを形成していることがわかる.

沈降によって分類された有機泥群（Case 2～7）では, 沈降速度の遅い有機泥群ほど，粒径が小さく，ILが大き く, $\mathrm{C} / \mathrm{N}$ 比が低い傾向にある。最も沈降速度の遅い有機 泥群（Case 7）に分類された有機泥には $21.6 \%$ の燃焼物 が含まれており，土粒子に付着する有機物の粒径の多く は $10 \mu \mathrm{m}$ 以下である（図-2，表-1）ことがわかる. Case 7 に含まれる有機物 (燃焼物) 量が最も多いことから，数 $\mu \mathrm{m}$ 程度の微細な有機物は同程度以下の粒径の土粒子に 
付着することが可能であり，有機物が付着することで沈 降し難い有機泥が形成されると推定される. 沈降の遅い 有機泥群には比較的新鮮な有機物が付着しているが, 付

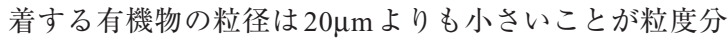
布（図-2）からわかる. 沈降速度が速く, ILの小さい Case 2 は逆に粒径の大きな粒子で構成されており，相対 的に有機物付着量が少ないために有機物付着の効果が薄 れ, 土粒子の持つ沈降速度に近い速度を持っていると推 定できる．なお，粒径の大きな粒子には炭素含有量の大 きい有機物が付着する傾向にある.

\section{(2) 平均光強度 SS 濃度関係と沈降泥の構造}

SALD-2000Jでは平均光強度（ALI）により粒子径が換 算されている.ALIは後方散乱光を測定することにより 求められている. ミー散乱では粒子径や粒子構造によっ て散乱強度分布が変化するため, ALI〜 SS 関係と, IL, $\mathrm{C} / \mathrm{N}$ 比等との比較から付着する有機物の状態を検討する ことができる（上野ら，2011）。ただし，フロック構造 を持たない粒子ではALI值は小さくなる特性もあるため, ALIのみでは付着有機泥の特性を知ることはできない. 図-3には沈降選別された有機泥群の ALI〜SS 関係が示さ れている.SSはALIに対して一意的に決まっていないの はSSが質量, ALIが体積の示標であること, 有機泥に付 着する有機物の量と性状により散乱強度が変化するため である.ALI〜SS関係に大きな差があるのはCase 2の有
機泥群である．選別されたCase 2の有機泥群が相対的に 最も散乱強度が弱いのは粒子が大きく，前節で述べた特 性により有機物の影響が小さいためと考えられる. Case 3〜7では有機泥群の異なる性状に伴う粒子構造の違いは 重量効果を除けばALIに反映されている.

\section{（3）選別された有機泥の沈降特性とフロック構造}

図-4には有機泥群の沈降に伴う粒度分布の経時変化, 図-5には超音波照射前後の粒度分布の変化が示されてい る. 図-4中の Initial は投入直後に測定された粒度分布で あり, $t=0$ は測定器内で流れが安定した後の試験開始時 間である. 図にCase 7の結果は示されていないが, 沈降 と超音波照射による変化はなく, 沈降も分離も起こって おらず，図-2に示したCase 7粒度分布から変化していな い. 図-4に示した粒度分布は装置に設置後約 25 分後まで の結果である．完全に沈降速度で選別できていたならば， 表-1に示した $5 \mathrm{~cm}$ 深での沈降時間を参照すればCase 2, 3 では全ての粒子が沈降, Case 5, 6では全ての粒子が残存 するはずである。しかし，図-4ではCase 2〜4の有機泥 群に残留する粒子が含まれており, Case 5では沈降する 粒子も存在している。これは，粒度分布を測定する前の 攪拌によって粒子のフロック構造が破壊され, Case 2 と 3 で沈降しない粒子, Case 4 と 5 で沈降速度の速い粒子が 出現したためと推定される。

図-5（b）ではCase 2の粒子群に超音波を照射した結果，
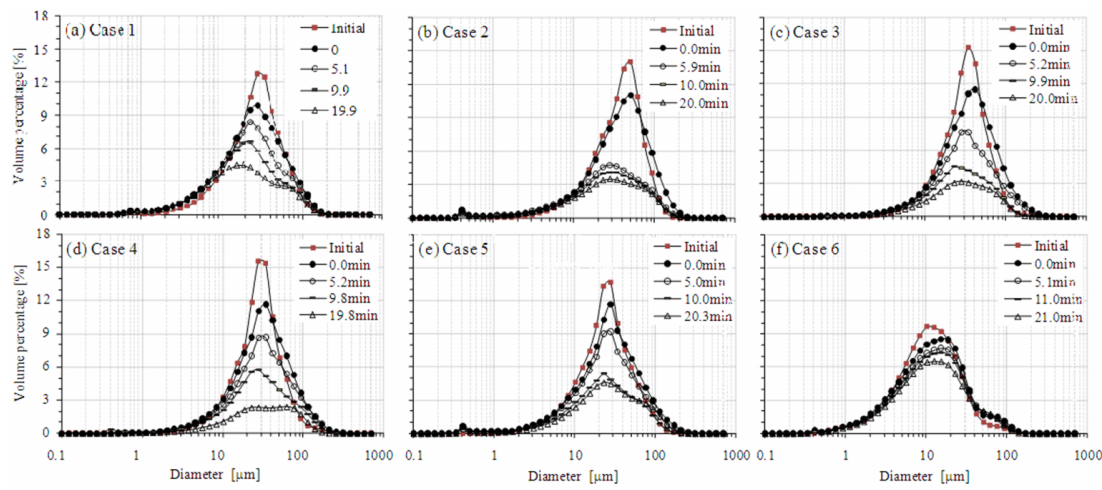

図-4 選別された有機泥群の沈降に伴う粒度分布の経時変化（Initial〜約20分まで）
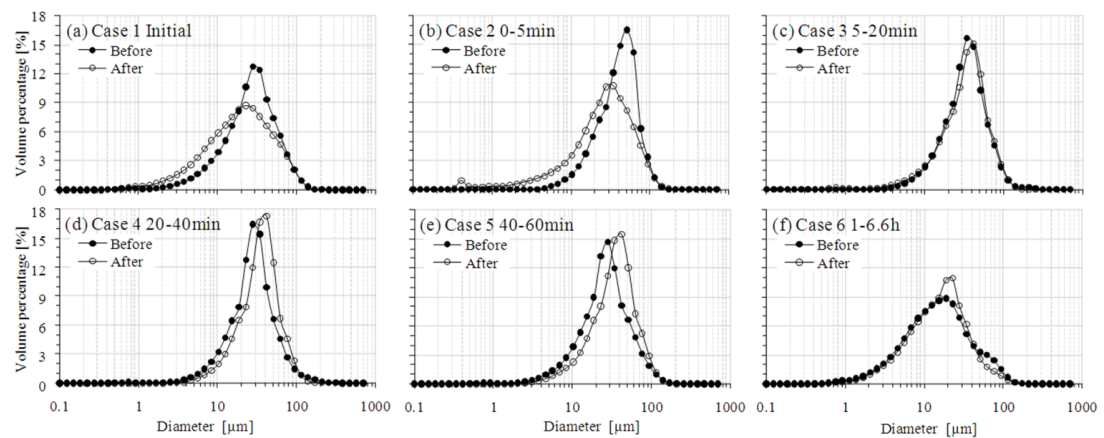

図-5 超音波照射前後の粒度分布の変化 


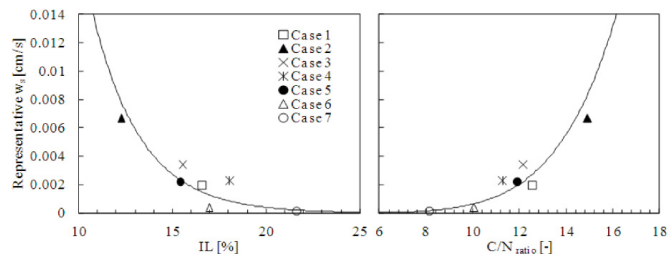

図-6 (a) 燃焼物重量 (IL) と代表沈降速度, (b) C/N 比と代表沈 降速度
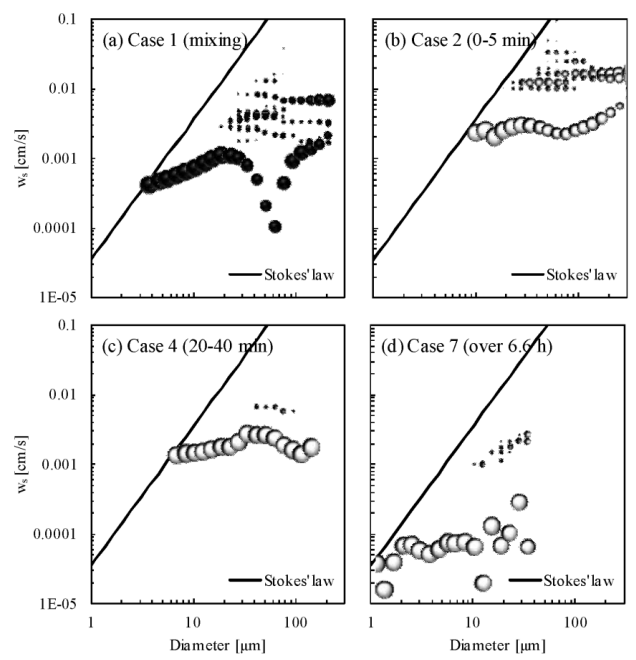

図-7 沈降速度分布 (a) 選別前, (b) (d) 選別後 [プロットサイズ は各粒径における沈降速度の頻度割合を示している]

フロック構造が壊れており， $30 \mu \mathrm{m} \sim 100 \mu \mathrm{m}$ の沈降速度 の速い粒子に $30 \mu \mathrm{m}$ 以下の微細粒子が付着していたこと がわかる。

図-4（b）で沈降しない粒子は沈降過程で緩く付着した 有機物粒子が沈降速度の速い粒子から分離したことが裏 付けられる. Case 4〜6の粒子は超音波により粒径が大 きくなって（膨張して）おり，フロック構造を有してい ることがわかる. Case 4 と 5 の有機泥群にも沈降速度の 速い粒子が含まれることから，Case 2 に比較して強く付 着したフロックからも攪拌によって有機物が外すことが できると考えられる．

\section{（4）沈降速度と有機泥特性}

各有機泥群に対する有機性状と沈降速度分布（図-7） の平均值（代表沈降速度）の関係を図-6に示した。沈降 選別された有機泥群は有機性状によっても選別されてお り, 沈降速度が速いほど, 有機物量が少なく, 比較的分 解の進んだ有機物が付着している。このことは，(3) 節 での推定を裏付けるものであり，フロック粒子の沈降速 度は付着する有機物の性状に依存することを示している。

図-7には選別前の沈降泥（Case 1)，選別後の沈降泥群 の代表例として沈降速度の最も速い沈降泥（Case 2), 中 間に位置する沈降泥 (Case 4), 最も遅い沈降泥 (Case 7) の沈降速度分布が示してある. 沈降速度分布のプロット

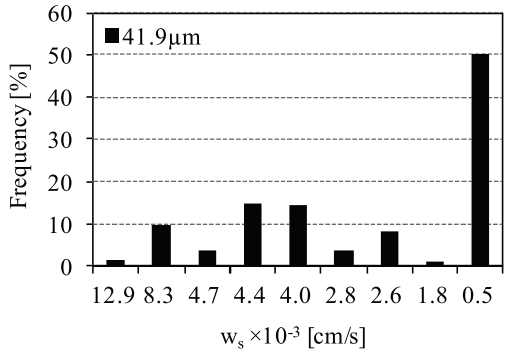

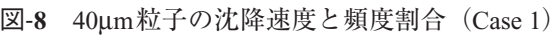

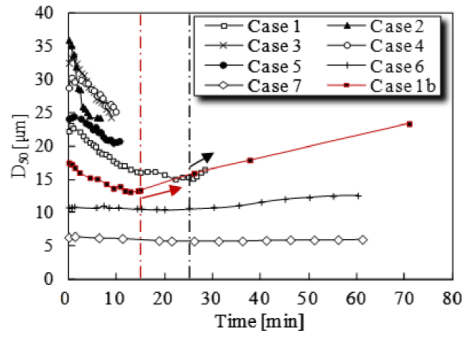

図-9 沈降中の有機泥群の中央粒径の経時変化

サイズは各粒径における沈降速度の頻度割合を表してい る. 選別後の沈降速度（図 (b) (d)) はCase 1の沈降速 度分布（図(a)）に比較して分布の広がりが小さく，沈 降速度別に選別されていることがわかる．またCase 2 （図（b））の沈降速度分布をみると, Case 1よりも速い沈 降速度を持つ粒子が存在する.これは様々な沈降速度を 持つ粒子が混在する場合には粒子間の干渉（衝突や凝集） を受け，沈降速度の差が減少されるためである。様々な 沈降速度（フロック構造）を持つ粒子が混在されると, 粒子の相互作用により沈降速度は均一化する方向に進む ことがわかる．選別された沈降泥の有機性状を考慮する と, 有機物の付着割合が少なく沈降速度の速い粒子 （Case 2）が有機物の付着割合の多い粒子（Case 7）の沈 降を加速させるが，自らの沈降を減速させることがわか る.なお, Case 2 の有機泥群は沈降選別時の沈降速度 (約 $0.02 \mathrm{~cm} / \mathrm{s})$ の $1 / 10$ 程度の速度になっているのに対し, Case 4 (図 (c)）では測定された沈降速度と選別時の沈降 速度が同オーダーの速度（5cm/40min）を示している. Case 2 の沈降選別は粒子濃度が最も高い時に行なわれて おり，水塊としての密度が高いことの影響を受けたため と考えられる。

Case 1 では粒径 $40 \mu \mathrm{m}$ 付近では幅広く沈降速度が分布し

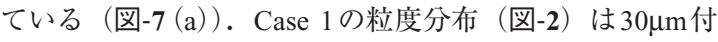
近に質量割合のピークがあり, 沈降速度の異なるCase 2

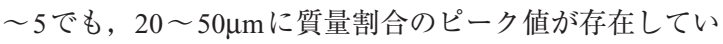
る.これらの関係は有機物量, $\mathrm{C} / \mathrm{N}$ 比の異なる沈降泥が $40 \mu \mathrm{m}$ 付近に多く存在することを示している。図-8に Case 1 における $41.9 \mu \mathrm{m}$ の粒径粒子の沈降速度〜頻度関係 を示した. 沈降速度の頻度割合は 10 倍程度ばらついてお 

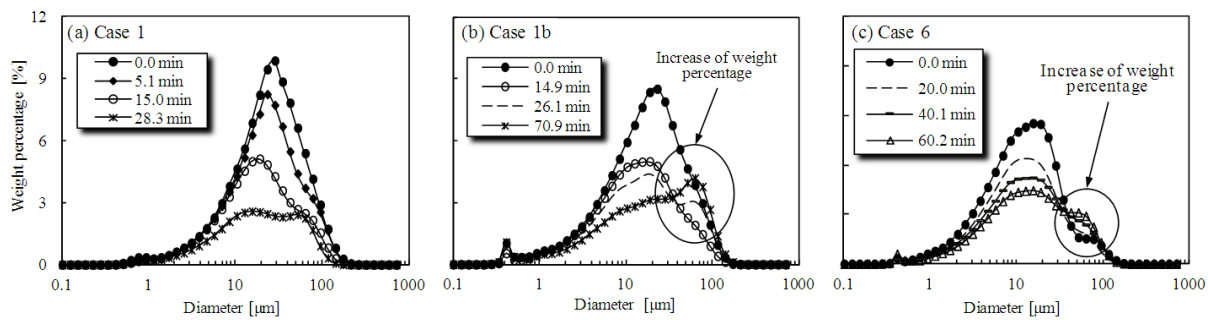

図-10 沈降過程で微細粒子のフロック化による粒度分布の変化

り, 有機特性の異なる有機物がフロック構造を形成し複 雑な状態で存在することがわかる.

\section{4. 沈降中の有機泥の凝集}

\section{（1）フロック構造が壊された粒子の沈降}

図-9は沈降中の有機泥群の中央粒径 $\mathrm{D}_{50}$ の経時変化を 示している. 小枝ら（2011）は， $\mathrm{D}_{50}$ の増加は主に粒子 相互の凝集によることを実験的に示しており, Case $1 \mathrm{~b}$ と Case 6での $\mathrm{D}_{50}$ の増加は凝集によるフロックの形成である と考えられる. なお, Case 1 においても 25 分以降に $\mathrm{D}_{50}$ が増大するのは, 選別前のCase 1 での有機泥群には遅い 沈降速度を持ち, 粒径の大きい粒子が存在しているため とも考えられる. 図-10には沈降に伴って中央粒径が増 加したCase $1,1 \mathrm{~b}$ とCase 6 の粒度分布の経時変化が示さ れている。粒度分布の質量割合のピーク值は経時的に $30 \mu \mathrm{m}$ 付近から $80 \mu \mathrm{m}$ 付近にシフトする傾向がある. フロ ック構造の異なる試料（Case 1, Case 1b）を比較すると, Case1bで質量割合の増加が顕著なピークの上昇が現れて おり，フロック構造を壊したことで沈降中に凝集性が高 い土粒子がフロック化していることがわかる.このこと は過酸化水素により有機物付着量が少なくなり, かつ化 学的にフロックが壊された粒子であっても, 再度フロッ ク化が起こることを示している.

\section{（2）有機物含有量と凝集メカニズム}

フロック構造が壊されたCase $1 \mathrm{~b}$ では 15 分以降に顕著 な $\mathrm{D}_{50}$ の増加が生じている (図-9). 中央粒径に着目すれ ば, Case 6, 7において凝集が生じることが予想されるが, Case 7では凝集が生じていない. Case 7 よりも ILが小さ く, C/N比が大きいCase 6 で数\%の粒子の凝集が起こっ ており, 凝集性は有機物量と有機性状に依存するといえ る. 有機物と無機物の存在条件では, 重力効果を無視で きる遅い沈降速度を持つ粒子はワァンデルワールスカの 効果を受け, 電気的に電荷符号が異なる有機物と無機物 との凝集が促進される. 沈降しない有機泥群（Case 7) を構成する土粒子は有機物が多く付着しており, 粒子が 同じ負電荷を持つため, 凝集の効果が小さい. Case $1 \mathrm{~b} て ゙$ は過酸化水素の添加によって有機物量が少なくなり，フ ロック構造が壊れ, 正電荷を持つ表面積が増加したため,
凝集し易い状態になったと考えられる。

\section{5. おわりに}

本研究で得られた結論は以下にまとめる.

a）有機泥の沈降特性は粒径のみならず，フロックを 形成する有機物（比較的分解の進んだ $10 \mu \mathrm{m}$ 以下の 粒子）量とその性状に依存する.

b）様々な沈降速度を持つ粒子群が混在する有機泥は 粒子間の干渉（衝突や凝集）を受け，沈降速度の 差が減少されるため, 沈降速度は均一化する方向 に進む。

c）有機物の付着する土粒子間では電気的に凝集は起 こり難いが, 有機物が除去されると正電荷を持つ 表面積が増加するため, 凝集が促進される.

\section{参 考 文 献}

Dietrich, W.E. (1982) : Settling velocity of natural particles, Water Resource Research, Vol.18, pp.1615-1626.

Eisma, D., P. Bernard, G. C. Cadee, V. Ittekot, J. Kalf, R. Laane, J. M. Martin, W. G. Mook, A.Van Put and T. Schuhmacher (1991) : Suspended-matter particle size in some West-European estuaries, Part 1: particle-size distribution, Netherlands Journal of Sea Research, Vol.28, pp.193-214.

Wilkinson, K.J., J.C. Negre and J. Buffle (1997) : Coagulation of colloidal material in surface waters: the role of natural organic matter, Journal of Contaminant Hydrology, Vol.26, pp.229-243.

阿部真己 · 今川昌孝 · 駒井克昭 · 日比野忠史 (2010)：河川感 潮域での有機泥輸送における塩分の働き, 水工学論文集, Vol.54, pp.1645-1650.

上野耕平・小枝豪志 - 中下慎也 - 日比野忠史（2011）：海底近 傍に形成される高濁度水の物理化学特性, 海岸工学論文 集, Vol.B2-67, No.2, pp.861-865.

内田一郎 (1987）: 浮遊へドロの問題点とその展望, 土と基礎, Vol. 26, No.1, pp.3-6.

小枝豪志・中下慎也・駒井克昭・日比野忠史（2010）：有機懸 濁物質の沈降過程に及ほす塩分の影響, 海岸工学論文集, Vol. B2-66, No.1, pp.1156-1160.

小枝豪志・TOUCH NARONG・日比野忠史（2011）：レーザ回 折式粒度分布計による細粒子の沈降速度推定手法の確立, 海岸工学論文集, Vol.B2- 67, No.2, pp.1051-1055.

金キョンへ・阿部真己・駒井克昭・日比野忠史（2009）：底泥 の巻き上がりに及ぼす浸透流の影響, 海岸工学論文集, Vol.B2-65, No.1, pp.971-975.

西村尚哉 - TOUCH NARONG - 駒井克昭 - 日比野忠史 （2009）：有機性状を考慮した有機懸濁質の沈降速度のモデ ル化, 海岸工学論文集, Vol.B2-65, No.1, pp.1151-1155. 